\title{
"INFLUENCE OF PROFITABILITY ACTIVA STRUCTURE TO CAPITAL STRUCTURE IN COMPANY INDUSTRY SECTOR AGRICULTURE LISTED IN BURSA EFEK INDONESIA PERIOD OF 2011 -2015"
}

\author{
Nurhana Dhea Parlina
}

\begin{abstract}
This research aimed to know empiric influencedfirm size and profitability together tocapital structured. Companies which are listed in Indonesia Stock Exchange and these companies have been selected by using purposive sampling. The research data is the secondary data which has been obtained fromthis sample based on criteria of this research 30 from the population. The output this reasearch is the same as from the theoryand journal forever with practice and application in the companies. That's means influenced of firm size and profitability to capital structure in company industry sector agriculture company listed in bursa efek indonesia in the years period of 2011-2015". The result is influenced profitability and activa structured to capital structure with together the proportion is $21,4 \%$.
\end{abstract}

Keywords : Profitability, Activa Structure, and Capital Structure

\begin{abstract}
ABSTRAK
Penelitian ini bertujuan untuk mengetahui secara empiris pengaruh ukuran perusahaan dan profitabilitas secara bersamaan terhadap struktur modal. Perusahaan terdaftar di BEI dan perusahaan telah berdasarkan pada kriteria pengambilan sampel yang disebut purposive sampling. Data dalam penelitian ini bersifat sekunder yang mana berdasarkan criteria penelitian 30 dari keseluruhan populasi. Hasil penelitian ini sama dari teori dan jurnal keduanya secara aplikasi dan prakteknya di dalam perusahaan. Artinya bahwa terdapat pengaruh profitabilitas dan struktur aktiva terhadap struktur modal pada perusahaan sektor industri pertanian yang terdaftar di bursa efek indonesia tahun 2011-2015". Hasil akhirnya adalah terdapat pengaruh perusahaan dan profitabilitas terhadap struktur modal secara bersama-sama dengan proporsi yang didapatkan21,4\%.
\end{abstract}

KataKunci : Profitabilitas, Struktur Aktiva dan Struktur Modal 


\section{PENDAHULUAN}

Perusahaan dituntut untuk beroperasi secara maksimal agar menghasilkan produk-produk yang berkualitas sehingga dapat mempertahankan kelangsungan hidupnya. Salah satunya adalah perusahaan sektor pertanian sebagai suatu identitas yang beroperasi yang tidak terlepas dari masalah permodalan atau dana pada umumnya yang tidak hanya berorientasi pada pencapaian laba namun juga berusaha untuk memakmurkan pemiliknya dalam meningkatkan profitabilitas perusahaan.Selainitu masalah struktur modal merupakan masalah yang sangat penting bagi setiap perusahaan, karena baik buruknya struktur modal akan mempengaruhi posisi finansial perusahaan. Struktur modal pada perusahaan dikatakan tidak baik jika, mempunya jumlah hutang yang lebih besar daripada modal sendiri yang akan memberi beban yang berat pada perusahaan. Selainitujuga, struktur aktiva memiliki peranan penting dalam menentukan pembiayaan perusahaan.

Struktur modal pada perusahaan dalam penelitian in imenggunakan debt to equity ratio (DER). Bisi International Tbk pada tahun 2011 mempunyai nilai DER tahun 2013 mengalami kenaikan sebesar 0,16, pada tahun 2014 mengalami kenaikan sebesar 0,17 , kemudian pada tahun 2015 mengalami kenaikan sebesar 0,18. Untuk PT. Astra Agro Lestari Tbk pada tahun 2011 mempunyai nilai DER sebesar 0,21, pada tahun 2012 mengalami kenaikan sebesar 0,33, pada tahun 2013 mengalami kenaikan sebesar 0,46 , pada tahun
2014 mengalami kenaikan sebear 0,57 kemudian pada tahun 2015 mengalami kenaikan 0,48. Untuk PT.Sampoerna Agro Tbk pada tahun 2011 mempunyai nilai DER sebesar 0,36, pada tahun 2012 mengalami kenaikan sebesar 0,55, pada tahun 2013 mengalami kenaikan sebesar 0,67 , pada tahun 2014 mengalami kenaikan sebesar 0,81, kemuadian pada tahun 2015 mengalami kenaikan kembali sebesar 0,99.

Sedangkan profitabilitas menggunakan ROI pada PT. Astra Argo Lestari, Tbk mengalami penurunan di tahun 2011 dari 0,25 menjadi 0,20 di tahun 2012 serta 2013 sebesar 0,13. Namun sayangnya di tahun 2014 sebesar 0,14 turun drastis 0,03. Disisi lain, struktur aktiva yang dimiliki PT. Tunas Baru Lampung Tbk pada tahun 2013 sampai dengan 2015 mengalami peningkatan struktur aktiva dari 0,59 menjadi 0,06.

$$
\text { Andi Kartika (2009). }
$$

Profitabilitas, struktur assets, pertumbuhan penjualan, ukuran perusahaan, struktur modal, Profitabilitas berpengaruh negatif terhadap struktur modal, struktur assets dan pertumbuhan penjualan tidak berpengaruh terhadap struktur modal, ukuran perusahaan berpengaruh positif dan signifikan terhadap struktur modal. Ida Bagus Made Dwija Bhawa dan Made Rusmala Dewi S (2015), Ukuranperusahaan, likuiditas, profitabilitas dan resiko bisnis terhadap struktur modal, Ukuran Perusahaan berpengaruh negatif tidak signifikan terhadap Struktur Modal, Likuiditas berpengaruh positif signifikan terhadap Struktur Modal, Risiko Bisnis berpengaruh 
positif tidak signifikan terhadap Struktur Modal. .Aliftia Nawang Sari dan Hening Widi Oetomo (2016), Profitabilitas, likuiditas, pertumbuhan assets ukuran perusahaan terhadap struktur modal, Profitabilitas berpengaruh negatif tidak signifikan terhadap struktur modal, Likuiditas berpengaruh negatif signifikan terhadap struktur modal, Ukuran perusahaan dan pertumbuhan assets berpengaruh positif tidak signifikan terhadap struktur modal.

Abraham Kelli SionWatung, Ivonne S. Saerang dan Hizkia H.D. Tasik (2016), Likuiditas, Aktivitas, Profitabilitas dan struktur aktiva terhadap struktur modal, Profitabilitas berpengaruh negatif tidak signifikan terhadap struktur modal, Likuiditas berpengaruh negatif signifikan terhadap struktur modal, Ukuran perusahaan dan pertumbuhan assets berpengaruh positif tidak signifikan terhadap struktur modal. Olehkarenaitu, peneliti ingin mengetahui hipotesis yang diajukan pada penelitian ini adalah :

$\mathrm{H}_{0}$ : tidak terdapat pengaruh profitabilitas, struktur aktivaterhadap struktur modal

$\mathrm{H}_{1}$ : terdapat pengaruh profitabilitas, struktur aktivaterhadap struktur modal

\section{Metode Penelitian}

Jenis penelitian yang digunakan dalam penelitian ini adalah dengan

Pemilihan sampel penelitian dapat dilihat di dalam tabel berikut ini :

Tabel 1.2

Pemilihan Sampel Penelitian

\begin{tabular}{|c|c|c|}
\hline No & Kriteria Sampel & $\begin{array}{c}\text { Jumlah } \\
\text { Perusahaan }\end{array}$ \\
\hline 1 & Perusahaan sektor pertanian yang terdaftar di Bursa & 21 \\
\hline
\end{tabular}

menggunakan asosiatif dalam Sugiyono (2012:150-151) dengan metode kuantitatif menurutSugiyono (2012:8).

\section{Populasi dan Sampel}

dalam penelitian ini adalah berjumlah 21 perusahaan sektor pertanian yang terdaftar di Bursa Efek Indonesia pada tahun 20112015. Teknik pengambilan sampel yaitu menggunakan teknik Purposive Sampling. Sampel yang digunakan dalam penelitian ini dipilih berdasarkan kriteria sebagai berikut :

1. Perusahaan yang termasukkedalamkelompokperu sahaansektorpertanian yang terdaftar di Bursa Efek Indonesia selamaperiode 20112015

2. Perusahaan sektorpertanian yang mempublikasikan laporan keuangannyaberturut-turut di Bursa Efek Indonesia (BEI) periodetahun 2011-2015

3. Perusahaan pertanian yang menggunakanmatauang Rupiah dalam laporan keuangannya di Bursa Efek Indonesia (BEI) padaperiodetahun 2011-2015.

4. Perusahaan yang mengaalami laba positif berturut-turut selama periode 2011-2015.

5. Perusahaan yang memiliki hutang jangka panjang berturutturut selama periode 2011-2015. 


\begin{tabular}{|c|l|c|}
\hline & Efek Indonesia (BEI) selama periode 2011-2015 & \\
\hline 2 & $\begin{array}{l}\text { Perusahaan sektor pertanian yang tidak } \\
\text { mempublikasikan laporan keuangannya berturut- } \\
\text { turut selama periode 2011-2015 }\end{array}$ & 0 \\
\hline 3 & $\begin{array}{l}\text { Perusahaan yang tidak menggunakan nilai mata } \\
\text { uang Rupiah }\end{array}$ & $\begin{array}{l}\text { P) } \\
\text { turut selama periode 2011-2015 }\end{array}$ \\
\hline 5 & $\begin{array}{l}\text { Perusahaan yang tidak memiliki hutang jangka } \\
\text { panjang berturut-turut selama periode 2011-2015 }\end{array}$ & 6 \\
\hline & Total JumlahSampel Perusahaan & 30 \\
\hline & Total jumlah Sampel Penelitian (6 X 5 ) & 6 \\
\hline
\end{tabular}

Sumber: Data sekunder yang telah diolah

Sumber data penelitian ini merupakan sumber data sekunder. Menurut Roscoe (1957) untuk menentukan ukuran sampel dalam Sekaran (2006:160) menyatakan bahwa Di mana ukuran sampel minimum 30. Menurut waktu pengumpulannya, penelitian ini menggunakan data time series diolah perhitungan dalam penelitian ini menggunakan alat bantu (software) program SPSS (Statistical Product and Service Solutions) versi 23.

Tabel 1.1

Operasinalisasi Variabel

\begin{tabular}{|c|c|c|c|}
\hline No & Variabel & Pengukuran & Skala \\
\hline 1 & $\begin{array}{c}\text { Dependen: } \\
\text { Struktur } \\
\text { Modal }(Y)\end{array}$ & DER $=\frac{\text { Total Hutang }}{\text { Modal Sendiri }} X 100 \%$ & Rasio \\
\hline 2. & $\begin{array}{c}\text { Independen: } \\
\text { Struktur Aset } \\
\left(\mathrm{X}_{1}\right)\end{array}$ & Struktur Aset $=\frac{\text { aktivatetap }}{\text { totalaktiva }} \times 100 \%$ & Rasio \\
\hline 3. & $\begin{array}{c}\text { Independen: } \\
\text { Profitabilitas } \\
\left(\mathrm{X}_{2}\right)\end{array}$ & $\mathrm{ROI}=\frac{\text { Earnings After Tax }}{\text { Total Assets }} \times 100 \%$ & Rasio \\
& & & \\
\hline
\end{tabular}

Sumber : Sartono (2012:225), AgusSartono (2012:248) dan Irham Fahmi (2013:80)

\section{Metode Analisis Data}

\section{Regresi Berganda}

Regresi Berganda digunakan untuk menguji hipotesis tentang dua variabel independen atau lebih secara bersama-sama dengan satu variabel dependen (Sugiyono, 2014:188). Persamaan regresi berganda yaitu sebagai berikut:

$$
Y=a+b_{1} X_{1}+b_{2} X_{2}
$$

Dimana:

$\mathrm{Y} \quad=$ Subyek variabel dependen a $\quad=$ Harga $\mathrm{Y}$ bila $\mathrm{X}=0$ (harga konstanta)

$\mathrm{b}_{1} \mathrm{x}_{1}=$ Koefisien regresi variabel dependen 
$\mathrm{x}_{1} \mathrm{x}_{2} \quad=$ subyek pada variabel independen yang mempunyai nilai tertentu

\section{Uji Signifikansi Simultan (Uji Statistik F)}

\section{HASIL PENELITIAN DAN PEMBAHASAN}

Tabel 2.1 Koefisien Determinasi

Model Summary

\begin{tabular}{|l|r|r|r|r|}
\hline Model & R & R Square & \multicolumn{1}{|c|}{$\begin{array}{c}\text { Adjusted R } \\
\text { Square }\end{array}$} & $\begin{array}{c}\text { Std. Error of the } \\
\text { Estimate }\end{array}$ \\
\hline 1 & $.518^{\mathrm{a}}$ & .269 & .214 & .70402 \\
\hline
\end{tabular}

a. Predictors: (Constant), ROI, STRUKTUR_ASET

Dari hasil tabel 2.1 di atas dalam model summary hal ini berarti $21,4 \%$ variasi struktur modal tidak dijelaskan oleh variasi ke tiga independen Ukuran Perusahaan dan

\section{Uji Asumsi Klasik}

Uji asumsi klasik yang digunakan adalah diantaranya multikolinieritas, autokorelasi, heteroskedastisitas, dan normalitas.

\section{Tabel 2.2 Uji Statistik F}

ANOVA $^{a}$

\begin{tabular}{|ll|r|r|r|r|r|}
\hline Model & & Sum of Squares & df & Mean Square & F & Sig. \\
\hline \multirow{3}{*}{1} & Regression & 4.915 & 2 & 2.457 & 4.958 & $.015^{\mathrm{b}}$ \\
& Residual & 13.382 & 27 & .496 & & \\
& Total & 18.297 & 29 & & & \\
\hline
\end{tabular}

a. Dependent Variable: DER

b. Predictors: (Constant), ROI, STRUKTUR_ASET

Dari hasil tabel 2.2 diatas dalam ANOVA bahwa hasil $\mathrm{F}$ hitung sebesar 4,958 dengan profitabilitas 0,015 karena probabilitasnya jauh lebih kecil dari 4,958 maka model regresi dapat digunakan untuk memprediksi struktur modal atau

Tabel 2.3 Uji Asumsi Klasik (Multikolinieritas)

Coefficient Correlations ${ }^{\mathrm{a}}$

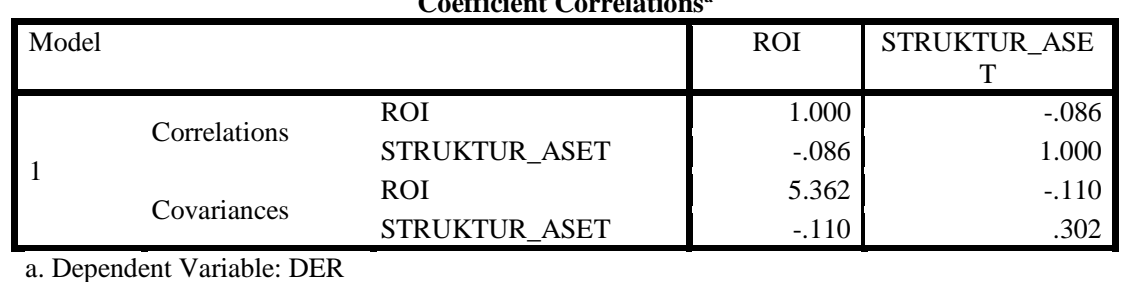

Melihat hasil tabel 2.4 bahwa besaran korelasi antar variable lindependen Ukuranperusahaan yang mempunyai korelasi cukup tinggi dengan variable profitabilitas (ROA) dengan tingkat korelasi sebesar 0,086 atau sekitar $-0,086 \%$ dapat dapat dikatakan bahwa ukuran perusahaan dan profitabilitas secara bersama-sama berpengaruh terhadap struktur modal.Uji asumsi klasik yang digunakan adalah diantaranya multikolinieritas sebagai berikut : 
dikatakan

tidak terjadi multikolinieritas yang serius.

Tabel 2.4 Uji Asumsi Klasik (Autokorelasi)

\begin{tabular}{l|r|r|r|r|r|}
\hline Model & R & R Square & $\begin{array}{c}\text { Adjusted R } \\
\text { Square }\end{array}$ & $\begin{array}{c}\text { Std. Error of the } \\
\text { Estimate }\end{array}$ & Durbin-Watson \\
\hline 1 & $.518^{\text {a }}$ & .269 & .214 & .70402 & 2.038 \\
\hline
\end{tabular}
a. Predictors: (Constant), ROI, STRUKTUR_ASET
b. Dependent Variable: DER

Nilai DW sebesar 2,038 dengan signifikansi $5 \%$, jumlah sampel 30 (n) dan jumlah variabel independen 2 $(\mathrm{k}=2)$, maka didapatkan nilai dari table durbin watson 2,038 lebih kecil dari batas atas du $=1,567$ dan kurang dari $4-1,567(4-1,567)$ atau dapat disimpulkan tidak terdapat autokorelasi.

Tabel 2.5 Uji Asumsi Klasik (Heteroskedastisitas)

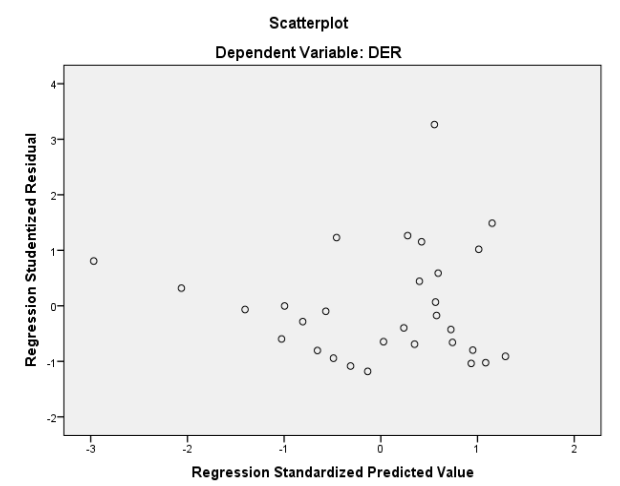

Dari grafik scatterplot 2.5 dapat disimpulkan bahwa tidak terjadi heteroskedastisitas

\section{Tabel 2.6 Uji Asumsi Klasik} (Normalitas)

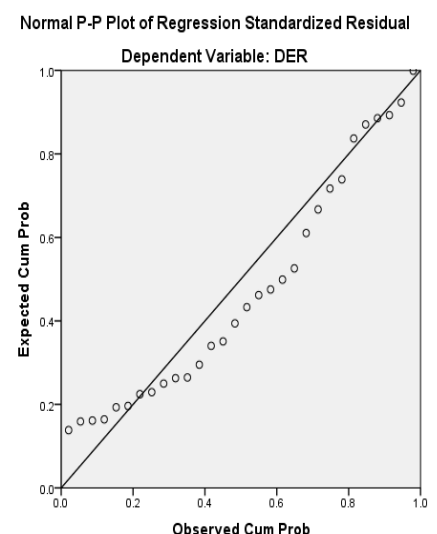

Pada grafik normal plot 2.6 menunjukkan bahwa pola distribusi normal, maka model regresi memenuhi asumsi normalitas.

\section{KESIMPULAN}

Berdasarkan hasil penelitian ini terdapat pengaruh profitabilitas dan struktur aktiva terhadap struktur modal secara bersama-sama dengan proporsi yang didapatkan $21,4 \%$

\section{DAFTAR PUSTAKA}

Abraham Kelli Sion Watung, Ivonne S. Saerang dan Hizkia H.D. Tasik (2016). Pengaruh Likuiditas, Aktivitas, Profitabilitas dan struktur aktiva terhadap struktur modal industri barang konsumsi di bursa efek indonesia. Universitas Samratulangi. Jurnal EMBA. ISSN 2303- 1174 Vol.4 No. 2 juni 2016.

AliftiaNawang Sari dan HeningWidi Oetomo (2016), Profitabilitas, likuiditas, pertumbuhan assets ukuran perusahaan terhadap struktur modal.

Bhawa, Ida Bagus Made Dwija Dewi S.,danNi Made Rusmala (2015). Pengaruh Ukuran perusahaan, likuiditas, profitabilitas dan resiko bisnis terhadap struktur modal. 
Universitas Udayana Vol 4, No. 7 (2015).

Fahmi, Irham. 2013. Pengantar Mananjemen Keuangan. Cetakan ke-2.

ALVABETA,CV:Bandung

Hanafi, Mamduh M. 2013. Manajemen Keuangan. Edisi 1. BPFEYOGYAKARTA:Yogyakarta Ghozali, Imam. 2016. Aplikasi Analisis Multivariate dengan Program IBM SPSS21. Edisi 7. Universitas Diponegoro : Semarang

Kartika, Andi (2009). Faktor-faktor yang mempengaruhi Struktur Modal pada perusahaan Manufaktur yang go public di BEI. Dinamika Keuangan dan Perbankan. Vol.1, No. 2

Riyanto, Bambang. 2015. Dasardasar Pembelanjaan Perusahaan. Edisi 4. BPFE YOGYAKARTA:

Yogyakarta

Sekaran, Uma. 2006. Metodologi Penelitian untuk Bisnis. Edisi 4. Jakarta:Salemba Empat

Sartono, Agus. 2012. Manajemen Keuangan Teori dan Aplikasi. Edisi $4 . \quad$ BPFE YOGYAKARTA Yogyakarta

www.idx.go.id 